\title{
Relevansi Teori Belajar Konstruktivisme Perpsektif Ibnu Khaldun Terhadap Karakteristik Belajar Siswa Milenial
}

\author{
Zahrotus Saidah* \\ Institut Agama Islam Negeri Syekh Nurjati Cirebon \\ Email: Email: zahrotussaidah@syekhnurjati.ac.id
}

\begin{abstract}
Millennials are generally individuals who have the ability to access knowledge widely and are more open to differences. This is because the millennial generation was born in a situation where there are many differences such as in race, ethnicity, culture, technology, language and so on. Thus, different learning strategies are needed that are more fun and able to provide meaning. This study aims to analyze how the relevance of Ibn Khaldun's constructivism learning with the learning characteristics of millennial students. This research is library research. The primary data in this study is a book by Ibn Khaldun entitled Mukaddimah. The secondary data used in the form of research reports, scientific journals and other works relevant to this study. The results of the analysis show that the concept of al-malakah which views that mastery of a knowledge, attitude, and skill is the impact of a learning process, this concept is in line with the character of millennial students, one of which is having a strong, independent and free entrepreneurial spirit. As for the concept of al-tadrij, which views that knowledge must be done gradually, because the human mind has a level of limitations, this concept is in accordance with the characteristics of millennial students, especially in utilizing information technology wisely. Therefore, these two learning theories, al-malakah and al-tadrij, must always be maintained so that students can construct knowledge based on their learning characteristics, and are able to obtain more meaningful learning..
\end{abstract}

Keywords: Ibn Khaldun, Constructivism, Millennial Students.

* Fakultas Tarbiyah Institut Agama Islam Negeri Syekh Nurjati Cirebon, Sunyaragi, Kec. Kesambi, Kota Cirebon, Jawa Barat 45132 


\begin{abstract}
Abstrak
Generasi milineal secara umum merupakan pribadi yang mempunyai kemampuan mengakses pengetahuan secara luas dan lebih terbuka terhadap adanya perbedaan. Hal ini disebabkan oleh karena generasi milenial terlahir pada situasi yang terdapat banyak perbedaan seperti pada ras, suku, budaya, teknologi, bahasa dan lain sebagainya. Dengan demikian diperlukan strategi pembelajaran yang berbeda yang lebih menyenangkan dan mampu memberikan kebermaknaan. Penelitian ini bertujuan menganalisis bagaimana relevansi pembelajaran konstruktivisme Ibnu khaldun dengan karakteristik belajar siswa milenial. Penelitian ini merupakan penelitian pustaka. Data primer dalam penelitian ini adalah kitab karya Ibnu Khaldun yang berjudul Mukaddimah. Adapun data skunder yang digunakan berupa laporan penelitian, jurnal ilmiah dan karya-karya lain yang relevan dengan studi ini. Hasil analisis menunjukkan bahwa konsep al-malakah yang memandang bahwa penguasaan terhadap suatu ilmu, sikap, dan keterampilan merupakan dampak dari suatu proses belajar, konsep ini sejalan dengan karakter perserta didik era milenial yang salah satunya adalah mempunyai jiwa entrepreneur yang kuat, mandiri dan bebas. Adapun pada konsep al-tadrij yang memandang bahwa pengetahuan harus dilakukan secara bertahap, karena akal manusia memiliki tingkat keterbatasan, konsep ini sangat sesuai dengan karakteristik siswa milenial, khususnya dalam memanfaatkan teknologi informasi dengan bijak. Oleh karenanya kedua teori belajar al-malakah dan al-tadrij ini, harus senantiasa dijaga agar peserta didik dapat mengonstruk ilmu pengetahuan berdasarkan karakteristik belajar mereka, dan mampu memperoleh pembelajaran yang lebih bermakna.
\end{abstract}

Kata Kunci: Ibnu Khaldun, Konstruktivisme, Peserta didik Milenial.

\title{
Pendahuluan
}

Pendekatan yang pada umumnya digunakan dalam proses pembelajaran adalah pendekatan konstruktivisme. Dalam pelaksanaanya pendekatan konstruktivisme sangat mengutamakan keterlibatan peserta didik dalam mengembangkan dan menemukan materi yang sedang dipelajari. Peserta didik dalam pendekatan ini di beri kesempatan untuk membangun pemahaman dan pengetahuan baru berdasarkan pengalaman yang diperolehnya. Peserta didik mengontruksi pengalaman yang diperolehnya secara berkesinambungan sehingga pengetahuan akan selalu mengalami perubahan. Dalam konsep ini, pendidik berperan untuk membantu proses pembelajaran agar pelaksanaan pembelajaran berjalan lancar.(Abdul Sani, 2014) 
Pengembangan teori kostruktivisme didasarkan pada teori kognitivistik Vygotsky.(Phillips, 1995) Mengutip penjelasan Doolitte dan Camp dalam International Encyclopedia of Education $3^{\text {rd }}$ Edition, bahwa dalam perkembangan selanjutnya, teori konstruktivisme ini kemudian dibedakan menjadi tiga; kognitif, radikal dan sosial.(Sjoberg, 2007) Di antara ketiga jenis tersebut, jenis konstruktivisme kognitif yang dikembangkan oleh Piaget yang menjadi teori konstruktivisme paling mutakhir Piaget,(Hudoyo, 1998) meskipun pada akhirnya teori ini menuai kritik, salah satunya kritik dari Vigotsky.(Swan, 2005)

Menurut Vygotsky, konstruktivisme kognitif Piaget terlalu individualistik dan sangat tergantung dengan motivasi internal. Selain itu, konstruktivisme kognitif tidak mengutamakan pada proses sosial. Atas kritikan tersebut, maka Vigotsky memunculkan gagasan teori konstruktivisme baru yang dinamakannya dengan konstruktivisme sosial.

Konstruktivisme sosial Vygotsky ini, pada dasarnya merupakan paham konstruktivisme yang menekankan proses pendidikan berdasarkan interaksi sosial, artinya bahwa pengetahuan peserta didik tidak hanya diperoleh dari pengalaman individu, namun juga berasal dari proses interaksi sosial.(Hua Liu, Charlotte \& Matthews, 2005)

Jauh sebelum para ahli mengembangkan teori belajar konstruktivisme, ilmuwan muslim sejatinya telah memiliki teori belajar yang serupa dengan konstruktivisme. Ilmuwan tersebut adalah Ibnu Khaldun, melalui karyanya yang luar biasa yaitu Muqaddimah. Ada 2 teori belajar yang ditawarkan oleh Ibnu Khaldun yaitu al-malakah dan al-tadri>j. Al-malakah diambil dari kata dasarnya maka diartikan dengan "menjadikan sesuatu yang dimiliki atau dikuasai". Al-malakah diartikan juga dengan "suatu sifat yang mengakar pada jiwa". Secara istilah al-malakah kemudian diartikan dengan sifat yang berurat berakar yang dimiliki peserta didik, yang diperoleh dari hasil belajar atau hasil dari sebuah kegiatan yang dilakukan secara berulang-ulang, sehingga hasil belajar atau hasil kegiatan tersebut menjadi kokoh tertanam dalam jiwa. Sedangkan al-tadrij secara bahasa merupakan kata bentukan dari asal katanya "tadarraja" yaitu naik/maju/meningkat secara berangsur-angsur atau sedikit-demi sedikit. Secara istilah, al-tadrij diartikan dengan peningkatan kemampuan yang dimiliki oleh peserta didik baik secara kualitas maupun secara kuantitas.(Ibn Khaldun waliyu al din, 2004) 
Teori al-malakah dan al-tadrij ini, dikembangkan oleh Ibnu Khaldun dengan berpijak pada pandangannya mengenai manusia dan fitfrah perkembangannya (natural development).(Walidain, 2005)

Teori belajar al-malakah dan al-tadrij yang ditawarkan oleh Ibnu Khaldun tersebut, memiliki kongruensi dengan teori belajar Gestalt,(Walidain, 2005) bahwa al-malakah merupakan teori belajar kognitif yang disertai dengan adanya insight, artinya konsep al-malakah Ibnu Khaldun ini, tidak hanya pada upaya meningkatkan kemampuan kognitif peserta didik, namun juga berupaya untuk meningkatkan kemampuan peserta didik dalam hal psikomotorik dan komponen afektif. Dengan demikian, Ibnu Khaldun memandang bahwa pengetahuan tidak hanya pada kemampuan untuk menghafal, namun bagaimana peserta didik dapat memaknai dan memahami terhadap pengetahuan yang telah dihafalkannya. Adapun teori belajar kedua yang ditawarkan oleh Ibnu Khaldun yaitu teori belajar al-tadrij, dalam pandangannya mengenai fitrah perkembangan manusia, maka Ibnu Khaldun memandang bahwa manusia memiliki keterbatasan, sehingga pengetahuannya harus diperoleh melalui tahapan-tahapan sistematis.

Diskursus tentang konstruktivisme sebagai salah satu pendekatan dalam proses memperoleh pengetahuan. Konstruktivisme terkait dengan bagaimana sebuah proses pembelajaran memiliki nilai tambah bagi peserta didik, termasuk juga bagi para peserta didik pada era milenial. Pada era ini, peserta didik dilahirkan dalam suatu lingkungan yang memiliki ketergantungan terhadap penggunaan teknologi informasi atau yang dikenal dengan era digital. Derasnya informasi pada era ini hampir sulit terbendung, sehingga pengetahuan dapat diperoleh oleh peserta didik dengan cepat dan mudah. Kondisi ini, disatu sisi menguntungkan, namun demikian kondisi ini menjadi tantangan tersendiri bagi pendidik. Pada era digital pendidik dituntut untuk memiliki kemampuan untuk melakukan pembelajaran secara berproses dengan karakteristik peserta didik pada era milenial.

International Education Advisory Board (IEAB) menyebutkan, ada tujuh ciri yang dimiliki oleh peserta didik generasi milenial: 1) Menyukai pilihan. Peserta didik pada era milenial ini lebih menyukai proses pembelajaran berbasis proyek, pemanfaatan teknologi dalam upaya pemecahan masalah atau tugas. 2) Mempunyai orientasi berkelompok. Peserta didik pada era milenial senantiasa memilki koneksi sosial yang lebih luas, sehingga memiliki kecenderungan untuk saling kolaboratif dan terbuka. 3) 
Inklusif. Peserta didik pada era milenial memiliki tingkat toleransi yang tinggi dari berbagai golongan, ras, agama. 4) Merupakan pengguna praktis teknologi digital. Peserta didik pada era milenial memiliki karakteristik spesifik yaitu ketergantungan terhadap media digital, sehingga teknologi informasi telah menjadi bagian dari Sebagian gaya hidup. Bagi generasi milenial, perangkat itu mampu menunjang pembelajaran dan mempermudah aktivitas lainnya. Teknologi terkini memungkinkan generasi milenial menyuarakan opininya melalui cara yang tak tersedia di masa lalu. 5) Berpikir berbeda. Peserta didik pada era milenial memandang bahwa informasi lebih penting daripada memikirkan babagaimana cara teknologi itu bekerja dalam menyediakan informasi. 6) Lebih berani mengambil risiko. Peserta didik pada era milenial akan mencoba metode baru jika metode lama tidak dapat lagi digunakan. 7) Tidak menghargai waktu. Peserta didik pada era milenial menganggap bahwa hidup tidak pasti, sehingga cenderung kurang bijak dalam penggunaan waktu secara baik.(Yuniastuti et al., 2021)

Dengan melihat karakteristik pembelajaran pada peserta didik era milenial di atas, apakah pembelajaran konstruktivisme menurut Ibnu Khaldun masih relavan? Guna menjawab pertanyaan ini, maka penelitian mengenai masalah yang telah diuraikan sebelumnya, menjadi penting untuk dilaksanakan.

Guna menjawab pertanyaan penelitian ini, maka peneliti menggunakan metode penelitian library research. Library research pada dasarnya adalah penelitian yang dalam pelaksanaanya hanya berdasarkan pada dokumen-dokumen yang telah ada sebelumnya. Dokumen tersebut berupa hasil penelitian yang dipublikasikan, karya ilmiah dalam bentuk buku, publikasi ilmiah dan lain sebagainya. Kendati merupakan salah satu bentuk dari penelitian, penelitian dengan library research tidak mengharuskan peneliti turun ke lapangan secara langsung untuk mendapatkan data penelitian. Data-data yang digunakan untuk menjawab masalah penelitia ini berupa data yang bersumber dari pustaka. Pada penelitian dengan model library research, penelusuran data dari perpustakaan bukan hanya merupakan langkah awal dalam menyiapkan research design, namun juga merupakan sumber data yang digunakan untuk melakukan analisis.(Melfianora, 2017)

Penelitian ini merupakan penelitian studi pustaka library research, karena penelitian dilakukan dengan menyandarkan pada studi atau karyakarya yang telah ditulis sebelumnya.(Aini, 2021) Sedikitnya ada tiga alasan 
mengapa library research digunakan dalam sebuah studi. Pertama, pertanyaan penelitian hanya dapat dijawab melalui penelitian kepustakaan dan bukan dilakukan di lapangan. Kedua, studi kepustakaan diperlukan sebagai fase terpisah dari studi introspektif (penelitian pendahuluan) guna memahami gejala baru yang sedang berkembang di lapangan secara mendalam. Ketiga, data yang berasal dari perpustakaan kredibel untuk dimanfaatkan dalam rangka menjawab pertanyaan dalam sebuah penelitian.

Data-data kepustakaan dalam penelitian berupa sumber kepustakaan sekunder dan primer. Sumber pustaka primer dimaksud pada penelitian ini adalah kitab Mukaddimah karya Ibnu Khaldun. Sementara sumber sekunder pada penelitian ini, berupa buku yang relevan, jurnal ilmiah yang dipublikasikan dan karya-karya lain yang relevan dengan tema penelitian.

Data-data yang berhasil dihimpun baik dari yang berasal dari sumber sumber primer dan sumber sekunder, kemudian dianalisis secara mendalam secara deskriptif. Secara operasional, proses analis data dalam penelitian library research dilakukan melalui 3 tahapan 1) Mengumpulkan data-data yang bersumber dari karya-karya yang telah dipublikasikan dan merupakan karya yang sejalan dengan masalah yang sedang dikaji. 2) Mengkategorisasikan data yang berhasil dihimpun kedalam satuan-satuan data yang relevan 3) Menafsirkan data yang berhasil dihimpun dan menarik kesimpulan dengan memperhatikan masalah penelitian dan kaidah dasar dalam proses penelitian.(Jalaluddin \& Khoerulloh, 2020).

\section{Hasil Penelitian dan Pembahasan}

1. Pembelajaran Konstruktivisme dalam Islam

Dalam Islam sudah dikenalkan beberapa teori belajar, kendati tidak disebutkan secara eksplisit, salah satunya teori belajar konstruktivisme. Teori belajar konstruktivisme dapat dilihat melalui ayat-ayat Alqur'an, Hadith, dan riwayat sahabat. Teori ini kemudian mencapai puncaknya pada zaman Ibnu Khaldun dengan dikembangkan secara konseptual ke dalam sebuah teori belajar. Terdapat beberapa bukti bahwa di dalam Alquran mengandung ayat yang memuat konsep pembelajaran konstruktivisme. Bukti tersebut ditunjukkan oleh:

Pertama, dalam surat ayat al-'Alaq ayat 1-5, 5 ayat awal surat al'Alaq ini menyerukan agar manusia senantiasa membaca dan menulis. 
Menanggapi hal ini maka Shihab, menjelaskan jika kata iqra' berakar kata dari qara'a yang memiliki makna menghimpun. Berdasarkan aktivitas iqra' yang bermakna menghimpun tersebut, kemudian melahirkan beragam makna seperti menyampaikan, menelaah, mengetahui, mendalami, meneliti, dan membaca baik teks baik teks yang tertulis atau teks yang tidak tertulis.(Quraish Shihab, 1996), (Nata, n.d.)

Selain perintah untuk membaca dalam lingkup makna yang luas, surat al-'Alaq 1-5 tersebut juga memuat makna perintah untuk menulis dengan pena dalam arti yang sangat luas. Makna untuk menulis dapat berupa merekam, menulis biasa, mendokumentasikan, memotret dan lain sebagainya. Pengetahuan yang akan didapatkan oleh peserta didik dari penerapan membaca dan menulis dalam lingkup makna yang luas, akan menjadi pengetahuan yang tersimpan dalam jangka waktu lama. Pengetahuan atau karya itu akan dibaca dan diteliti oleh generasi selanjutnya.(Nata, n.d.)

Kedua, salah satu karakter dari teori belajar konstruktivisme adalah memotivasi peserta didik. Motivasi ini dapat berupa memotivasi sikap rasa ingin tahu, yang diwujudkan dalam bentuk peserta didik agar aktif untuk bertanya, menyelesaikan masalah melalui kegian tanya jawab, berdialog, dan lain sebagainya. Terkait dengan hal tersebut ayat-ayat dalam Alquran juga terdapat beberapa ayat yang mencirikan pembelajaran konstruktivisme dengan banyak bertanya, bereksperimen dan juga melalui pengalaman yang dari setiap orang.

Ayat dalam Alquran yang mengandung makna tersebut banyak ditemui. Ayat yang mengadung makna tersebut dapat dikenali pada ayat yang diawali dengan kata tanya atau isim istifham. Isim istifham yang banyak digunakan dalam bentuk pertanyaan, contohnya madha>, hal, ma>, ayyu, 'amma, man dan lain-lain.(Abbas Nadwi, 1996) Teks ayat yang mengandung pertanyaan juga ditunjukan dalam bentuk kalimat sa'ala, selain menggunakan isim istifham Bentuk tanya jawab yang terdapat dalam ayat-ayat Al-quran, membuktikan jika Al-quran telah memberikan gambaran bahwa proses mendapatkan pengetahuan dimulai dengan mengajukan pertanyaan. Melalui pertanyaanpertanyaan yang diajukan kemudian manusia berupaya mendapatkan jawabannya baik berdasarkan pengalaman dirinya sendiri ataupun pengalaman orang lain. Salah satu bentuk dialog konstruktif dikisahkan dalam dialog Nabi Ibrahim saat mencari kebenaran konsep Tuhan, yang dijelaskan melalui surat Al-An'am ayat 74-79. 
Adapun terkait dengan konstruktivisme sosial, terdapat juga dalam Alquran dan dapat diamati melalui ayat-ayat yang berkaitan dengan konsep ummah, qaum dan lain-lain. Sementara itu, materi konstruktivisme kognitif juga terdapat dalam ayat Alquran dijelaskan melalui anjuran tadabbarun, ta'qilun, tafaqqahun, tafakkarun, dan lainnya. Alquran juga memuat materi pembelajaran yang terkait dengan life skill. Hal ini dapat dipahami pada ayat- ayat yang menunjukkan bahwa beberapa Nabi yang dikisahkan memiliki keahlian tertentu, seperti Nabi Daud sebagai pandai besi, Nabi Idris sebagai seorang yang pandai menjahit, dan lain sebagainya.(Nata, n.d.)

Karakter dari teori konstruktivisme juga terdapat dalam hadishadis Nabi. Salah satu contoh hadits Nabi yang memuat teori konstruktivisme yaitu hadits Ibnu Muslim mengenai pertanyaan atas siapakah orang yang bankrut. Nabi Muhammad SAW bersabda yang maknanya

"Siapakah orang yang bankrut itu? "sahabat menjawab bahwa orang yang dikatakan bangkrut jika orang tersebut tidak mempunyai dirham (uang) dan tidak mempunyai harta. Kemudian Nabi Muhammad SAW bersabda muflis dari umatku adalah orang yang datang pada hari kiamat membawa (pahala) shalat, puasa, dan zakat namun (ketika di dunia) dia telah mencaci dan (salah) menuduh orang lain, memakan harta orang lain, menumpahkan darah orang lain, memukul orang lain (tanpa hak). Maka orang- orang itu akan diberi pahala dari kebaikan- kebaikannya, jika telah habis kebaikankebaikan- nya, maka dosa-dosa mereka akan ditimpakan kepadanya, kemudian dia akan dilemparkan ke dalam neraka."(Yunia Fauzia, 2015)

Dari kutipan hadis di atas dapat diketahui jika Nabi Muhammad SAW memanfaatkan dialog atau tanya jawab dalam rangka menggali pengetahuan para sahabatnya tentang siapa orang yang dikatakan bangkrut. Konteks pertanyaan Nabi Muhammad kepada para sahabat pada hadis tersebut tidaklah menunjukkan bahwa Nabi Muhammad SAW tidak mengetahui seorang yang bangkrut, namun Nabi Muhammad memberikan kesempatan kepada sahabat untuk menyampaikan pendapatanya mengenai kriteria seorang yang bangkrut. Para sahabat kemudian merespon, dengan memberikan jawaban atas pertanyaan Nabi Muhammad SAW. Setelah sahabat menyampaikan jawaban, kemudian Nabi SAW kemudian memberikan jawaban yang sesuai kehendak Allah. 
Dilihat dari teori belajar konstruktivisme Vygotsky, tindakan Nabi SAW, pada dasarnya adalah bentuk dari scaffolding. Scaffolding merupakan proses yang dapat dimanfaatkan oleh orang tua dalam membimbing anaknya sesuai dengan zona perkembangan proksimalnya. Apabila orang tua telah memberikan dukungan belajar kepada anaknya secara terstruktur maka tahap selanjutnya anak dapat belajar secara mandiri.

2. Pembelajaran Konstruktivisme dalam Teori Belajar Ibnu Khaldun.

Melalui karya monumentalnya yaitu kitab Muqaddimah Ibnu Khaldun berhasil merumuskan teori belajar al-malakah dan al-tadrij. Kedua teori yang telah dirumuskan oleh Ibnu Khaldun tersebut pada dasarnya dikembangkan berdasarkan pandangannya tentang fitrah perkembangan manusia dan manusia itu sendiri.(Walidain, 2005)

Teori al-malakah yang dikembangkan oleh Ibnu Khaldun memiliki kongruensi dengan teori Gestalt, namun menurut Walidain memiliki perbedaan yang mendasar. Teori Gestalt hanya mencakup aspek kognitif, sementara teori al-malakah Ibnu Khaldun menekankan pengetahuan hanya dilihat pada aspek kognitif, namun juga harus memperhatikan aspek lain yaitu psikomotorik dan afektif peserta didik. Pengetahuan menurut Ibnu Khaldun tidak cukup dengan menghafal, namun harus juga paham. Dengan demikian Ibnu Khaldun menyatakan bahwa al-fahmu, dan al-wa'yu memiliki perbedaan. Al-Fahmu yang artinya pemahaman dimaksud adalah pemahaman yang merupakan kemampuan dalam menangkap makna, dapat memberikan penjelasan dengan kemampuan menyusun kalimat secara mandiri, dan atau dapat memberikan contoh lain dari yang sebelumnya dicontohkan oleh pendidik, atau dapat menerapkan petunjuk yang telah diberikan untuk diterapkan pada konteks lain. Adapun al wa'yu yang diartikan hafalan disini adalah hafalan yang kongruen dengan hafalan dalam taxonomi bloom, yaitu daya simpan berbagai informasi, pengetahuan, dan symbolsimbol. Sementara pemahaman memiliki jenjang yang lebih tinggi daripada hafalan. Meski demikian menurutnya, untuk mendapatkan pengetahuan yang lebih tinggi maka hafalan tetap dibutuhkan.(Walidain, 2005) Dapat dikatakan bahwa teori al-malakah Ibnu Khaldun adalah proses belajar yang merupakan suatu penguasaan sikap, materi keilmuan, dan keterampilan yang diperoleh akibat dari adanya pelaksanaan pembelajaran yang sistematis dan sungguhsungguh.(Ibn Khaldun waliyu al din, 2004) 
Ibnu Khaldun berpandangan jika akal manusia adalah potensi psikologis yang memiliki fungsi untuk mendapatkan ilmu pengetahuan. Akal fikir merupakan induk dari segala aktivitas(Muhammad Naquib al Attas, 1980) dan merupakan potensi psikologis, memiliki tingkatantingkatan yaitu al-'aqlu al-tamyi>zi, al-'aql al- tajri>bi dan al-'aql alnaz)ari.(Ibn Khaldun waliyu al din, 2004)

Walidain menjelaskan bahwa kerja akal sebagaimana konsep dari Ibnu Khaldun menunjukkan bahwa akal dapat bekerja secara maksimal jika proses kerja akal dilakukan melalui tahapan-tahapan perkembangan dari akal tersebut. Perkembangan tersebut dimulai dari ketika manusia mempunyai kemampuan untuk membedakan al-tamyiz. Sebelum altamyiz, manusia tidak mempunyai ilmu sama sekali. Setelah melalui altamyiz kemudian manusia akan mencapai sensual perception dan kemampuan dalam berfikirnya.(Walidain, 2005)

Dalam pandangan Ibnu Khaldun, berfikir adalah sebuah proses dinamis dari aktivitas psikologis dalam diri manusia. Berfikir adalah wujud dari kreativitas yang merupakan perpaduan antara intelek dan rasio. Objek empiris dapat diterima oleh rasio, akan tetapi essensinya hanya akan dipahami oleh intelektual manusia. Dengan demikia akal akan mengambil kesimpulan dengan benar. Perpaduan dari rasio dan intelektual dapat meningkatkan kesadaran yang lebih tinggi dalam rangka memahami sesuatu yang berada di luar dirinya sendiri. Oleh sebab itu akal dapat digunakan untuk mengolah informasi-informasi yang diterima oleh panca indera, untuk kemudian informasi itu akan dikembalikan kepada rasio dan mengalohanya. Adapun akal selanjutnya menganalisisnya dan mensintesiskan informasi yang didapatkannya dari panca indera sebagai cara berfikir yang tepat atau benar.(Walidain, 2005) Ketika sudah memadukan antara rasio dan daya intelektual ini maka peserta didik dapat dikatakan telah mencapai al-malakah.(Ibn Khaldun waliyu al din, 2004) Dalam konteks taxonomi Bloom, hafalan dan pemahaman pada dasarnya adalah domain kognitif,(Sofyan et al., 2006) akan tetapi hafalan dan pemahaman termasuk kedalam tingkatan yang rendah dalam proses mendapatkan pengetahuan.(Walidain, 2005)

Teori belajar kedua yang dikembangkan oleh Ibnu Khaldun adalah teori belajar al-tadrij. Teori belajar al-tadrij beranggapan jika manusia memiliki keterbatasan dan kerja akal dapat berjalan secara maksimal jika digunakan secara bertahap. Oleh sebab itu, guna memaksimalkan akal maka proses belajar dilakukan sejalan dengan tahapan kerja akal 
manusia, dalam arti belajar harus disesuaikan dengan tahapan kerja akal yang perlahan dan berkelanjutan. Teori belajar al-tadrij yang dikembangkan oleh Ibnu Khaldun juga disinyalir memiliki kongruensi dengan teori belajar yang ditawarkan oleh Spencer. Spencer menjelaskan jika jiwa manusia terdiri atas respon-respon atau tanggapan, bayangan yang yang terdapat dalam ingatan pasca manusia melakukan pengamatan.(Egan, 2002) Menurut teori konstruktivisme yang dicetuskan Piaget, respon atau tanggapan diibaratkan sebagai konsep awal dalam sebuah pengetahuan. Konsep ini untuk selanjutnya menjadi pijakan dalam merekonstruksi pengetahuan baru. Dengan demikian menurut teori konstruktivisme Piaget pengetahuan baru dapat terbentuk Ketika manusia telah mengalami proses akomodasi, asimilasi, dan equilibration.(Yamin, 2005)

3. Relevansi Pembelajaran Konstruktivisme Ibnu Khaldun dengan Kebutuhan peserta didik Milenial

Jauh sebelum para ahli mengembangkan teori belajar konstruktivisme, ilmuwan muslim sejatinya telah memiliki teori belajar yang serupa dengan konstruktivisme. Ilmuwan tersebut adalah Ibnu Khaldun. Melalui karyanya yang luar biasa yaitu Muqaddimah, ada teori pembelajaran yang ditawarkan oleh Ibnu Khaldun yaitu teori belajar almalakah dan al-tadri>j. Kedua teori tersebut berpijak pada pandangan Ibnu Khaldun mengenai manusia dan fitfrah perkembangannya.(Walidain, 2005)

Teori belajar al-malakah yang ditawarkan oleh Ibnu Khaldun tersebut, memiliki kongruensi dengan teori belajar Gestalt. Dalam pandangan teori belajar Gestalt, konsep belajar al-malakah bermakna sebagai pencerahan. Akan tetapi konsep pencerahan menurut Walidain, cenderung hanya menyentuh pada aspek kognitif, adapun konsep almalakah Ibnu Khaldun, menyentuh pada tiga sspek kognitif, psikomotorik dan juga aspek afektif. Dengan demikian, Ibnu Khaldun memandang bahwa pengetahuan tidak hanya pada kemampuan untuk menghafal, namun bagaimana peserta didik dapat memaknai dan memahami terhadap pengetahuan yang telah dihafalkan. Dalam toeri belajar al-malakah proses belajar tidak ahanya pada asepk kognitif, namun tetapi mencakup psikomotorik dan afektif, dengan demikian belajar pada dasarnya adalah upaya yang dilakukan dalam rangka mencapai ketiga aspek tersebut. Terdapat dua cara untuk melaksanakan al-malakah menurut Walidi yaitu latihan dan kontunitas.(Walidi, 2000) 
Teori belajar kedua yang ditawarkan oleh Ibnu Khaldun adalah teori belajar al-tadrij. Dalam teori ini manusia memiliki keterbatasan sehingga pengetahuan harus diperoleh melalui tahapan-tahapan sistematis. Dengan kata lain, belajar harus dilakukan secara bertahap seuai dengan kadar akal manusia, untuk itu belajar harus disesuaikan dengan tahapan kerja akal, berkelanjutan dan secara bertahap. Teori belajar al-tadrij selanjutnya diadopsi oleh Pestalozzi. Pestalozzi menjelaskan jika proses pembelajaran harusnya dilakukan melalui tahapan-tahapan dari pengetahuan sederhana kemudian pada pengetahuan yang rumit. Proses pembelajaran juga harus dilakukan dari yang dapat diamati kemudian pada pengetahuan yang mengandalkan rasio. Proeses pembelajaran juga dapat dilakukan dari pengetahuan yang parsial menuju pada pengetahuan yang umum.(Walidain, 2005) Teori belajar al-tadrij yang dikembangkan oleh Ibnu Khaldun juga disinyalir memiliki kongruensi dengan teori belajar yang ditawarkan oleh Spencer. Spencer menjelaskan jika jiwa manusia terdiri atas responrespon atau tanggapan, bayangan yang yang terdapat dalam ingatan pasca manusia melakukan pengamatan.(Egan, 2002) Menurut teori konstruktivisme yang dikembangkan Piaget respon atau tanggapan diistilahkan sebagai konsep awal dalam mendapatkan pengetahuan. Konsep ini untuk selanjutnya menjadi pijakan dalam merekonstruksi pengetahuan baru. Dengan demikian menurut teori konstruktivisme Piaget pengetahuan baru dapat terbentuk Ketika manusia telah mengalami proses akomodasi, asimilasi, dan equilibration.(Yamin, 2005)

Menurut Ibn Khaldun(Ibn Khaldun waliyu al din, 2004) terdapat beberapa metode pembelajaran yang dapat diterapkan diantaranya sebagai berikut:

1. Metode Pentahapan atau tadarrûj.

Pelaksanaan pembelajaran pada metode ini adalah pelaksanaan pembelajaran hendaknya dilaksanakan sedikit-demi sedikit, bertahap dan secara berangsur-angsur. Pada metode ini dapat dilaksanakan dengan memulai pembelajaran dari penyampaian masalah yang mendasar pada tiap materi pembelajaran. Pada tahap ini, seorang pendidik harus mampu memberikan penjelasan masalah secara umum pada tiap bagian materi pembelajaran. Hal ini dilakukan dengan tujuan agar peserta didik mendapat pemahaman yang menyeluruh mengenai cabang ilmu yang sedang dipelajarinya. Harapan yang hendak dicapai adalah peserta didik mampu 
melakukan memetakan terhadap masalah yang sedang dibahas. Dengan demikian, metode tadarrûj ini sejalan dengan kondisi psikologis peserta didik, yang pada dasarnya tidak memiliki kemampuan untuk menerima materi pembelajaran dalam jumlah banyak dalam satu waktu.

Menurut Ibn Khaldun pada metode pentahapan, materi yang disampaikan tingkat pertama harus materi yang bersifat umum. Dengan demikian peserta didik akan memiliki pengetahuan umum yang memadai mengenai suatu masalah. Ibn Khaldun menyampaikan bahwa "keterangan-keterangan yang disampaikan oleh pendidik harus bersifat umum dan komprehensip dengan memperhatikan kesiapan dan kemampuan akal peserta didik untuk mendapatkan pemahaman.(Iqbal, 2015)

Ibn Khaldun memiliki keyakinan jika pembelajaran dapat dikatakan efektif jika pembelajaran yang dilaksanakan secara bertahap dan perlahan-lahan. Metode pentahapan ini dilakukan dengan tujuan untuk memberikan kesempatan pada otak agar dapat berfikir dan menyerap informasi secara maksimal terhadap materi yang disampaikan oleh pendidik. Selain itu, metode pentahapan dapat membuat peserta dapat menyimpan endapan pengetahuan yang tersusun secara sistematis, sehingga dapat membentuk pengetahuan yang komprehensip atau utuh. Keutuhan pengetahuan ini dimungkinkan apabila peserta didik mendapatkan materi secara berangsur-angsur dan bertahap. Ilmu pengetahuan yang berangsurangsur dan bertahap diharapkan dapat membentuk sebuah bangunan ilmu yang komplit.(Unsi, 2018)

2. Metode Pengulangan atau tikrâri

Pada metode tikrâri sangat menekankan aspek pengulangan dalam proses pembelajaran. Ibnu Khaldun menyampaikan bahwa penguasaan dan keterampilan terhadap suatu pengetahuan merupakan dampak atau akibat dari kebiasaan atau kegiatan yang dilakukan secara berulang-ulang. Lebih lanjut Ibnu Khaldun, menjelaskan jika metode pembiasaan dan pengulangan dapat memberikan kemungkinan kepada peserta didik agar memahami prinsip dan kaidah keilmuan yang sedang dipelajari.(Fakhruddiana, 2017)

Ibnu Khaldun menghendaki agar pendidik memberikan memperhatikan terhadap proses pembelajaran sesuai dengan potensi 
yang ada pada seorang peserta didik. Pada proses ini pendidik harus mampu menggali potensi peserta didik yang sesuai dengan kebutuhannya. Guna menggali potensi peserta didik terntu saja memerlukan proses dan waktu yang tidak singkat. Disisi lain waktu berdampak negative terhadap kemampuan untuk menyimpan memori atau informasi. Akan tetapi dampak negative tersebut dapat diatasi dengan melakukan pengulanganan secara bekesinambungan.(Unsi, 2018)

Ibn Khaldun memandang bahwa pengetahuan pendidik tidak harus memberikan semua pengetahuannya kepada peserta didik, karena otak peserta didik bukanlah wadah yang harus diisi dengan berbagai informasi. Dengan demikian otak pada dasarnya adalah sebuah potensi yang dimiliki manusia untuk terus dapat berkembang dan tumbuh, dan siap untuk memperoleh suatu informasi atau pengetahuan secara bertahap.(Susanto, 2009) Dengan demikian materi pelajaran memerlukan pembiasaan dan pengulangan sebagai salah satu cara untuk memantabkan pemahaman ilmu yang telah diperoleh. Metode pengulangan perlu diterapkan karena dengan mengulang-ulang tingkat kesiapan peserta didik untuk memahami ilmu pengetahuan secara bertahap.

3. Metode Tadrîb

Metode selanjutnya yang ditawarkan oleh Ibn Khaldun adalah metode tadrîb. Metode ini menekankan bahwa dalam mengajarkan ilmu dapat dilakukan melalui lapangan dan latihan terjun langsung kelapangan atau praktek. Metode ini merupakan lanjutan setelah proses penyampaian materi berupa teori. Dengan kata lain metode tadrîb merupakan lanjutan dari metode selanjutnya. Metode ini diperlukan untuk meningkatkan kemahiran terhadap penguasaan materi yang telah disampaikan.(Iqbal, 2015)

Dari metode pembelajaran yang disampaikan oleh Ibn Khaldun di atas dapat dikatakan bahwa pembelajaran konstruktivisme menurut Ibnu Khaldun relevan untuk diterapkan pada peserta didik Milenial. Sebagaimana Hampton dan Key yang menyatakan bahwa generasi milenial merupakan pribadi yang berpengetahuan luas mengenai perbedaan. Generasi ini terlahir pada situasi yang beragama baik dalam hal ras, suku, budaya, teknologi dan lain sebagainya.(Cilliers, 2017) Karakteristik peserta didik pada generasi milenial menurut Daud diantaranya 1) Kenyamanan dan kebebasan dalam penggunaan 
teknologi informasi. 2) Multitasking pada produk teknologi informasi dan peralatan digital. 3). Memiliki akses informasi yang tinggi, sehingga meningkatkan tanggung jawab sosial. 4) Terhubung dengan banyak orang melalui media sosial.(Daud, 2020) Sementara itu hasil studi Northeastem University ada lima kunci pada peserta didik generasi milenial diantaranya 1) Memiliki jiwa entrepreneur yang bebas, kuat, dan mandiri. 2) Mempunyai perhatian lebih tinggi terhadap pendidikan tinggi dan mandiri. 3) Memiliki kepedulian yang tinggi terhadap keuangan. 4) Mengutamakan interaksi antar pribadi. 5) Progresif dalam kebijakan kesehatan, kebijakan sosial, hak dan hukum yang setara.(Daud, 2020)

Secara umum penerapan pembelajaran konstruktivistik menurut Ibnu Khaldun sedikitnya memberikan tiga manfaat bagi masa depan peserta didik era milenial yaitu: 1) peserta didik memiliki daya ingat yang tinggi terhadap informasi, 2) Peserta didik memiliki keahlian atau kemampuan dalam mengaitkan suatu konsep yang diterimanya dengan konsep lain, sehingga dapat memudahkan dalam menerima pengetahuan dalam proses belajar selanjutnya. 3) Peserta didik belajar lebih mudah untuk belajar terhadap hal-hal yang serupa walaupun peserta didik mungkin telah lupa terhadap isinya, akan tetapi peserta didik pernah mengalaminya, dan pada akhirnya akan memudahkan peserta didik untuk mengingat informasi tersebut.(Saidah, 2021)

\section{Kesimpulan}

Secara umum penerapan pembelajaran konstruktivistik menurut Ibnu Khaldun sedikitnya memberikan tiga manfaat bagi masa depan peserta didik era milenial yaitu: 1) Peserta didik memiliki daya ingat yang tinggi terhadap informasi, 2) Peserta didik memiliki keahlian atau kemampuan dalam mengaitkan suatu konsep yang diterimanya dengan konsep lain, sehingga dapat memudahkan dalam menerima pengetahuan dalam proses belajar selanjutnya. 3) Peserta didik belajar lebih mudah untuk belajar terhadap hal-hal yang serupa walaupun peserta didik mungkin telah lupa terhadap isinya, akan tetapi peserta didik pernah mengalaminya, dan pada akhirnya akan memudahkan peserta didik untuk mengingat informasi tersebut. Melalui konsep al-malakah Ibnu Khaldun menyatakan bahwa belajar tidak hanya untuk mendapatkan pemahaman dan mendapatkan informasi yang tersimpan dalam memori. Al-malakah menyangkut pada semua aspek yaitu kognitif, psikomotorik dan afektif. 
Oleh karena itu, konsep al-malakah akan memberikan kemudahan bagi para pendidik dalam penyampaikan materi, karena karakter perserta didik era milenial yang salah satunya adalah emiliki jiwa entrepreneur yang kuat, bebas dan mandiri. Sementara itu melalui konsep al-tadrij Ibnu Khaldun menyatakan bahwa guna mendapatkan pemahaman suatu pengetahuan tertentu tidak dapat dilakukan dalam waktu singkat, namun harus dilakukan secara bertahap. Dengan demikian pada era milenial konsep ini juga harus senantiasa dijaga agar peserta didik dapat memahami bagaimana memanfaatkan teknologi informasi dengan bijak.

\section{Daftar Pustaka}

Abbas Nadwi, A. (1996). Belajar Mudah Bahasa Al Qur'an. Mizan.

Abdul Sani, R. (2014). Inovasi Pembelajaran. Bumi Aksara.

Aini, Q. (2021). Analysis of The Comparative Islamic Economic Thinking Between Abu Yusuf, Ibnu Taimiyah and Ibnu Khaldun. Dinar: Jurnal Ekonomi Dan Keuangan Islam, 8(1), 35.

Al-Zarkasyi, B. al-D. M. bin A. (1979). al-Burhan Fi 'Ulum al-Qura'an (D. Al-Fikr (ed.)).

Arifin, H. M. (n.d.). Masyarakat, Pendidikan Islam Dalam Arus Dinamika. Golden Terayon Press.

Bloom, B. S. (1979). Taxonomy of Education Objectives, Hand Books I Cognitive Domain. New Impression: Longmans.

Cilliers, E. J. (2017). The Challenge of Teaching Generation Z. People. International Journal of Social Sciences, 3(1), 188-198.

Daud, A. (2020). Strategi Guru Mengajar di Era Milenial. Al-Mutharahah, 17(1), 34 .

DeVries, R. (n.d.). Vygotsky, Piaget, and Education, A Reciprocal Assimilation of Theories and Educational Practices. University of Northern Iowa: Regent's Center for Early Developmental Education. 
Egan, K. (2002). Getting it wrong from the beginning: our progressivist inheritance from Herbert Spencer, John Dewey and Jean Piaget (V.-B. Press (ed.)).

Egan, K. (2009). Pengajaran yang Imajinatif. PT Indeks.

Fakhruddiana, F. (2017). Pendidikan Berperspektif Psikologi Islam: Gagasan Ibnu Khaldun, Cara Nabi Muhammad SAW \& Telaah Surah Lukman. Psikologika, 22(1), 55.

Hua Liu, Charlotte \& Matthews, R. (2005). Vygotsky's philosophy: Constructivism and its criticism examined. International Education Journal, 6(3), 387-391.

Hudoyo, H. (1998). Ilmu Pendidikan. Usaha Nasional.

Ibn Khaldun waliyu al din, A. al R. I. M. (2004). Muqaddimah Ibnu Khaldun (Bab 6, Juz). Dar Yu'rab. al Maktabah al Shamilah

Iqbal, A. M. (2015). Pemikiran Pendidikan Islam: Gagasan-gagasan Besar Para Ilmuwan Muslim. Pustaka Pelajar.

Jalaluddin, \& Khoerulloh, A. K. (2020). Prinsip Konsumsi dalam Islam: Tinjauan Terhadap Perilaku Konsumen Muslim dan Non-Muslim. Jurnal Ekonomi Syariah Dan Bisnis, 3(2), 155.

Junaedi, M. (2010). Ilmu Pendidikan Islam, Filsafat dan Pengembangan. RaSAIL Media Group.

Melfianora. (2017). Penulisan Karya Ilmiah dengan Studi Literatur. UPT Balai Penyuluhan Pertanian.

Muhammad Naquib al Attas, S. (1980). The Concept of Education in Islam. http://mef-ca.org/files/attas-text-final.pdf.

Nata, A. (n.d.). Pendidikan dalam Perspektif Al Qur'an. UIN Jakarta Press.

Phillips, D. C. (1995). The Good, the Bad, and the Ugly: The Many Faces of Constructivisme. Educational Researcher, 24(7), 6. 
Quraish Shihab, M. (1996). Wawasan Al Qur'an Tafsir Maudlu'i atas Pelbagai Persoalan Umat (Cet.3). Mizan.

Saidah, Z. (2021). Pendidikan Berbasis Konstruktivisme dalam Meningkatkan Kebermaknaan Belajar di Era Digital. Wahana Islamika: Jurnal Studi Keislaman, 7(2), 168.

Sjoberg, S. (2007). Constructivism and learning. In International Encyclopedia of Education (3rd Editio, p. 2).

Sofyan, A., Feronika, T., \& Burhanuddin. (2006). Evaluasi Pembelajaran IPA Berbasis Kompetensi. UIN Jakarta Press.

Sofyan, A., Feronika, T., \& Burhanuddin. (2006). Evaluasi Pembelajaran IPA berbasis Kompetensi. UIN Jakarta Press.

Susanto, A. (2009). Pemikiran Pendidikan Islam. SInar Grafika Offset.

Swan, K. (2005). Elements of Quality Online Education: Engaging Communities. MA: Sloan-C.

Thaha, A. (2014). Muqaddimah Ibnu Khaldun. Pustaka Firdaus.

Unsi, B. T. (2018). Konsep Metode Pembelajaran Ibn Khaldun dalam Pengajaran Bahasa Arab. Murabbi, 2(1), 65.

Walidain, W. (2005). Konstelasi Pemikiran Pedagogik Ibnu Khaldun Perspektif Pendidikan Modern. Suluh Press.

Walidi, W. (2000). Teori Belajar Malakah dan Tadrij Ibnu Khaldun. Ta'dib, 2(3), 69-70.

Yamin, M. (2005). Paradigma Pendidikan Konstruktivistik: Implementasi KTSP \& UU No. 14 Tahun 2005 Tentang Guru dan Dosen. Gaung Persada Press.

Yunia Fauzia, I. (2015). Mendeteksi Kebangkrutan secara Dini Perspektif Ekonomi Islam. Ekuitas: Jurnal Ekonomi Dan Keuangan, 19(1), 96. 
Al-Tarbawi Al-Haditsah: Jurnal Pendidikan Islam

Vol. 6 No. 2 Desember 2021
pISSN: 2407-6805

eISSN: 2580-6505

Yuniastuti, Miftakhuddin, \& Khoiron, M. (2021). Media Pembelajaran

Untuk Generasi Milenial Tinjauan Teoritis dan Pedoman Praktis. Scopindo Media Pustaka. 